\title{
Glass Ionomer Cements can be used for Bonding Orthodontic Brackets After Cancer Radiation Treatment?
}

Gabriela Cristina Santin ${ }^{1,2}$, Alexandra Mussolino de Queiroz ${ }^{3}$, Regina Guenka Palma-Dibb 4 , Harley Francisco de Oliveira ${ }^{5}$, Paulo Nelson Filho ${ }^{3}$, Fábio Lourenço Romano ${ }^{3}$

\begin{abstract}
Patients undergoing radiotherapy treatment present more susceptibility to dental caries and the use of an orthodontic device increases this risk factor due to biofilm accumulation around the brackets. The objective of this study was to evaluate the shear bond strength to irradiated permanent teeth of orthodontic brackets bonded with conventional glass ionomer cement and resin-modified glass ionomer cement due to the fluoride release capacity of these materials. Ninety prepared human premolars were divided into 6 groups $(n=15)$, according to the bonding material and use or not of radiation: CR: Transbond XT composite resin; RMGIC: Fuji Ortho LC conventional glass ionomer cement; GIC: Ketac Cem Easymix resin-modified glass ionomer cement. The groups were irradiated (I) or nonirradiated (NI) prior to bracket bonding. The specimens were subjected to a fractioned radiation dose of 2 Gy over 5 consecutive days for 6 weeks. After the radiotherapy, the brackets were bonded on the specimens with Transbond XT, Fuji Ortho LC and Ketac Cem Easymix. After $24 \mathrm{~h}$, the specimens were subjected to shear bond strength test. The image of enamel surface (classified by Adhesive Remnant Index - ARI) was also evaluated and its frequency was checked among groups/subgroups. The shear bond strength variable was evaluated with ANOVA and Tukey's post-hoc test. GIC group showed the lowest adhesion values among the groups $(p<0.05)$. There was no statistically significant difference among non-irradiated and irradiated groups ( $p>0.05)$. As for the ARI, the CR-I group showed the highest material retention on enamel surface among the irradiated groups. RMGIC group showed the highest values for shear bond strength and presented ARI acceptable for clinical practices.
\end{abstract}

'Department of Dentistry, UEM- Universidade Estadual de Maringá, Maringá, PR, Brazil ${ }^{2}$ Department of Dentistry, UNINGÁ - Centro Universitário lngá, Maringá, PR, Brazil ${ }^{3}$ Department of Pediatric Dentistry, School of Dentistry of Ribeirão Preto, USP - Universidade de São Paulo, Ribeirão Preto, SP, Brazil ${ }^{4}$ Department of Restorative Dentistry, School of Dentistry of Ribeirão Preto, USP - Universidade de São Paulo, Ribeirão Preto, SP, Brazil ${ }^{5}$ Department of Medical Clinic, Medical School of Ribeirão Preto, USP - Universidade de São Paulo, Ribeirão Preto, SP, Brazil

Correspondence: Gabriela Cristina Santin, Avenida do Café, s/n, 14040-904, Ribeirão Preto, SP, Brasil. Tel:+55-16-3602-4116. e-mail: gabsantin1310@gmail.com

Key Words: radiotherapy, glass ionomer, dental enamel, orthodontics brackets, shear bond strength.

\section{Introduction}

With the advancement of cancer treatment (1) and early diagnosis of the disease (2), survival and cure rates increased. Thus, more and more Orthodontists will be required to treat patients with cancer history (3). However, there is need for more information about dental complications of orthodontic treatment in patients after radiotherapy and the development of protocols to be followed in these cases $(4,5)$.

Patients treated with ionizing radiation in head and neck region may develop permanent changes in the salivary glands, excreting saliva with ineffective buffer capacity $(6,7)$. In addition, changes in the organic and inorganic substrate of the tooth can make them more susceptible to demineralization (8-10). The combination of these factors enables development of caries lesions, which may arise from three weeks to one year after radiotherapy (8).

The increasing success rates for cancer patients treated with radiotherapy and the occurrence of tooth loss during treatment, led to an increased demand for orthodontic treatment after radiotherapy. Thus, in some cases, the patient with radiotherapy history may need orthodontic treatment for bracket bonding on enamel surface. A previous study demonstrated that the enamel of irradiated teeth supports the bonding of orthodontic brackets (11).

However, as the patient is more susceptible to dental caries due to changes caused by ionizing radiation, the use of orthodontic appliances will add one more risk factor, due to the propensity of biofilm accumulation around brackets. Thus, the bonding of orthodontic brackets could also be carried out with conventional glass ionomer cement or resin-modified glass ionomer cement, which has fluoride release capacity, reducing the risk of dental caries (12).

However, bonding of these materials has low adhesion to enamel, frequently not withstanding the orthodontic mechanical and masticatory forces (13). Nevertheless, there are no articles in published literature evaluating the resistance of bonded brackets shearing with glass ionomer cements in teeth subjected to radiation.

The objective of this study was to evaluate the shear bond strength and the adhesive remaining index in metal orthodontic brackets bonded with and resin-modified GIC on permanent irradiated teeth. The tested hypothesis was 
whether the brackets bonding with glass ionomer cement will provide adequate retention to enamel after exposure to ionizing radiation.

\section{Material and Methods}

This study was previously submitted to appreciation and approval of the Ethics Research Committee of University of São Paulo - Brazil (Case No. 662331); the samples were obtained from the same University's tooth bank.

The sample consisted of 90 human extracted premolars (the first and second premolars, maxillary and mandibular). Inclusion criteria were: teeth with complete root formation, without dental wear, cracks, fractures, structural abnormality or traces of restorations; and no orthodontic, endodontic or chemical treatment history. After selection, the teeth were stored in a $0.1 \%$ thymol solution for one week for disinfection and afterwards washed in tap water for $24 \mathrm{~h}$.

For specimen preparation, the tooth crown was covered with acrylic self-curing resin and the buccal surface of each tooth pressed on a glass plate before setting reaction. Then, this same face was polished with \#400,600 and 1200 wet sand paper (DP-902 polisher; Struers A/S, Copenhagen, Denmark) until obtaining an enamel area of about $5 \mathrm{~mm}^{2}$ for bonding the brackets. The specimens were evaluated in stereomicroscope only to visualize enamel in $\times 4$ magnification (Bioptika L20, Colombo, PR, BR).

The teeth were included in PVC tubes using a device with a base plate, two fixed perpendicular plates on the sides, a plate fixed horizontally covering half the base plate and a fourth perpendicular plate fixed on the side plates. Next, the roots of the teeth were included and centralized in PVC tubes of approximately $1.5 \mathrm{~cm}$, filled with self-curing acrylic resin. This device, in addition to helping the inclusion of tooth roots in PVC tubes, provided perpendicularity between the tooth and tube base (Fig. 1). This pattern was used to check parallelism between the exposed enamel surface and the shearing chisel during mechanical testing, since any change in this angle may alter the results of the test.

Once completed, the samples were randomly divided into 6 groups $(n=15)$, according to the bonding material and

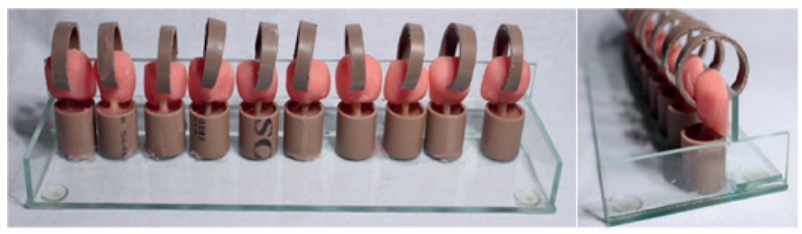

Figure 1. Device for inclusion of tooth roots in PVC tubes and produced perpendicularity between the tooth and tube base. use or not of radiation: CR: Transbond XT composite resin; GIC: Fuji Ortho LC resin-modified glass ionomer cement; RMGIC: Ketac Cem Easymix conventional glass ionomer cement. All prepared samples were stored in artificial saliva in an oven at $37^{\circ} \mathrm{C}$ for $24 \mathrm{~h}$ and were either irradiated (I) or non-irradiated (NI) prior to bracket bonding, at the Radiotherapy Department of the Medical School's Clinical Hospital, Brazil.

During the radiation procedure, the samples were placed in a plastic box, immersed in deionized water to maintain a humid environment simulating the oral cavity. At the end of procedure, the deionized water was discarded and the specimens were stored in artificial saliva (14) in a hothouse at $37{ }^{\circ} \mathrm{C}$ until the next radiation, when the saliva was again replaced with deionized water. Artificial saliva was not used during radiation because of the high ion concentration, which could interfere with the direct radiation per unit area $(11,15)$. Water is the main constituent of human tissues and immersion in distilled water during radiotherapy may simulate the soft tissues, physically and chemically, liberating free radicals $(11,15)$.

The specimens were subjected to a fractioned dose of 2 Gy over 5 consecutive days for 6 weeks (weekly dose, 60 Gy) (9-11).

An irradiator designed for biological research (RS 2000, Rad Source Technologies, Inc., Suwanee, GA, USA) was used for the X-ray emission at $200 \mathrm{kVp}$ and $25 \mathrm{~mA}$ and a 0.3 $\mathrm{mm}$ default copper filter. The $\mathrm{X}$-rays in these conditions have a spectrum of minimum and maximum energy values of $95 \mathrm{kV}$ to $200 \mathrm{kV}$, respectively, and half the beam with $0.62 \mathrm{~mm}$ of copper.

The dose gradient of these $\mathrm{X}$-rays in tissues is about $10 \%$ up to about a $0.5 \mathrm{~cm}$ depth. The plates were aligned equidistant from the center of the beam and inside of the cone to ensure uniform rate dose (approximately $2.85 \mathrm{~Gy}$ / $\mathrm{min}$ ) and total delivery of the dose per fraction.

Quality control was performed using dosimeters (Nanodot; Landauer Inc., Glenwood, IL, USA), and the dose readings on the surface of the plates used to calculate treatment time "beam-on". The dosimeters were placed below the irradiated plates and calibrated in accordance with the beam conditions described above. After the radiation, the specimens were kept in artificial saliva at $37^{\circ} \mathrm{C}$ for $24 \mathrm{~h}$ before bonding the brackets.

Before the bracket bonding, a circular area of $5 \mathrm{~mm}$ diameter was defined using adhesive tape with a hole in the center, on the buccal surface of the teeth.

Then, this area had prophylaxis with extra-fine pumice paste and deionized water, with rubber cup at low speed for $10 \mathrm{~s}$, washed for $10 \mathrm{~s}$ and dried with an oil and moisturefree triple syringe. Each rubber cup was used on five teeth only, to avoid that wear of the rubber undermines the 
efficacy of the prophylaxis.

For the RC, enamel conditioning was made with $37 \%$ phosphoric acid for $15 \mathrm{~s}$, followed by an air/water jet for 10 $\mathrm{s}$ and dried for $10 \mathrm{~s}$. Next, a thin layer of union XT Primer agent (3M Unitek, USA, Monrovia, Calif), was evenly spread on the marked area and light-cured with Ultra Blue LED unit (DMC, Plantation, FL, USA). Composite Transbond XT (3M Unitek) was applied on the surface of the brackets (Roth Standard 18, L12RL, Morelli, Sorocaba, SP, Brazil), which were positioned and pressed with a pincer (Ortoply, Philadelphia, PA, USA) on the demarcated vestibular areas.

Excess of composite around the brackets was removed with the blunt tip of an exploratory probe, followed by photoactivation on the mesial, distal, incisal and cervical regions for $10 \mathrm{~s}$ each. The light intensity of the apparatus was measured with a radiometer (Demetron, Danbury, CT, USA), keeping the light intensity at $600 \mathrm{~mW} / \mathrm{cm}^{2}$.

For RMGIC, the enamel conditioning was made with $37 \%$ phosphoric acid for $15 \mathrm{~s}$, followed by an air/water jet wash for $10 \mathrm{~s}$ and dried for $10 \mathrm{~s}$. The bracket was then bonded with resin-modified glass ionomer cement by Fuji Ortho LC resin (GC Corporation, Tokyo, Japan) and photoactivated in the mesial, distal, incisal and cervical $\vec{\Xi}$ areas for $10 \mathrm{~s}$ on each.

For GIC the enamel conditioning was made with $37 \%$ phosphoric acid for $15 \mathrm{~s}$, followed by an air/water jet wash for $10 \mathrm{~s}$ and dried for $10 \mathrm{~s}$. The brackets were then bonded with the conventional glass ionomer cement Ketac Cem Easymix (3M ESPE, St. Paul, MN, USA). For the shear bond test, the active tip of the universal testing machine's scooper was positioned at the interface between bracket and enamel. After $24 \mathrm{~h}$, the samples were subjected to the shear bond strength test with the testing machine at a vertical speed of $0.5 \mathrm{~mm} / \mathrm{min}$ with a load cell of $20 \mathrm{kgf}$.

After removing the bracket, the enamel of all the samples was evaluated by stereomicroscope loupe in $\times 4$ amplification (Bioptika) and classified based on the Adhesive Remnant Index (ARI), according to the scores proposed by Artun and Berglan (16): 0 - no adhesive left on the enamel; 1 - less than half of the adhesive left on the enamel; 2 - more than half of the adhesive left to the enamel; 3 - all composite resin adhered to the enamel.

The "Adhesive Remaining Index" variable (ARI) was distributed in the contingency table, checking the frequency between groups/subgroups. The shear bond strength variable was evaluated with ANOVA and Tukey post-hoc test. Data were analyzed using the statistical program Bioestat 5.3 and the significance level was 5\%.

\section{Results}

In the data analysis, GIC presented the lowest adhesion values, different from the others $(p<0.05)$ and similar to the CR and RMGIC groups ( $p>0.05)$ (Table 1).

Comparing the subgroups (between irradiated and non-irradiated specimens), despite the radiated subgroup presenting numerically higher bond strength values to than CR and RMGIC groups, there was no statistically significant difference between subgroups, as well as in the interaction between the variables type of cement and irradiation.

Analyzing ARI, the radiated and bonded with composite resin (CR-I) subgroup showed greater retention of composite on enamel surface (ARI greater than 1). However, CR-NI, RMG-I, RMG-NI, GIC-I and GIC-NI showed a higher frequency of score 0 , without adhered material to the enamel (Fig. 2).

\section{Discussion}

The hypothesis of this study was partially confirmed, since only the resin-modified glass ionomer cement showed adherence similar to that obtained by the use of orthodontic composite.

The orthodontic corrective treatment requires the bonding of brackets to enamel surface, to maintain the tooth movement. In an in vitrostudy, Santin et al. (11) found that the radiated enamel was less resistant to cohesive microshear test, compared to non-radiated enamel, while the adhesion of metallic brackets bonded with different

Table 1. Mean and standard deviation values of the adhesive shear bond strength $(\mathrm{MPa})$ of orthodontic brackets in the groups and subgroups $(\mathrm{n}=90)$

\begin{tabular}{lcc}
\hline Group & Non-irradiated & Irradiated \\
\hline CR (Transbond XT) & $17.8 \pm 5.4^{\mathrm{a}}$ & $21.2 \pm 4.5^{\mathrm{a}}$ \\
RMGIC (Fuji Ortho LC) & $17.6 \pm 2.9^{\mathrm{a}}$ & $19.5 \pm 6.5^{\mathrm{a}}$ \\
GIC (Ketac Cem Easymix) & $12.8 \pm 2.5^{\mathrm{b}}$ & $12.7 \pm 2.2^{\mathrm{b}}$ \\
\hline
\end{tabular}

Same letters indicate no statistically significant difference ( $p>0.05$; ANOVA and Tukey's test).

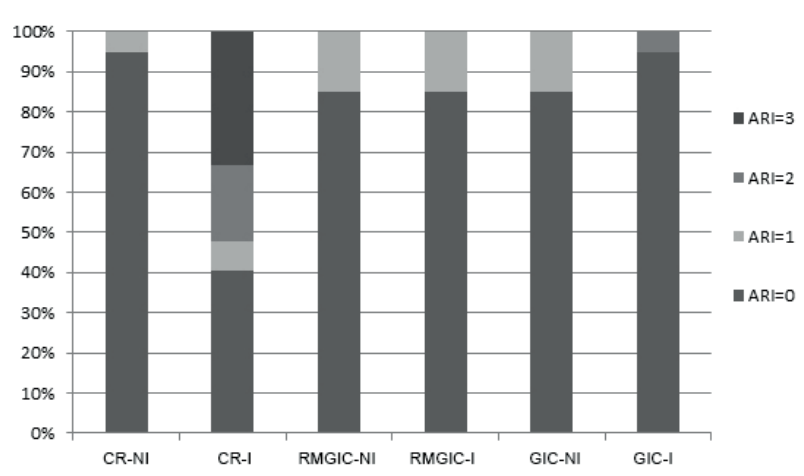

Figure 2. Frequency of ARI scores according to the experimental groups. CR (composite resin; Transbond XT). RMGIC (resin-modified glass ionomer cement; Fuji Ortho LC). GIC (glass ionomer cement Ketac Cem Easymix). NI: Non-irradiated. I: irradiated. 
composites showed satisfactory result.

In this study, it was chosen to evaluate the bonding of brackets with glass ionomer cement on teeth subjected to ionizing radiation, due to the absorption property and fluoride release of this material. The concepts related to the anticariogenic action were demonstrated. However, the fluoride released in low but constant concentrations in the oral cavity for long periods, has shown to be more efficient (17). The presence of fluoride in the oral cavity, influencing the suitability of the medium and, more particularly, its contact at the tooth/composite interface, has great importance in the prevention of demineralization and in the remineralization of enamel and dentin exposed to the acid challenge (17). The supply of fluoride ions may occur through the fluoride water, topical applications of fluoride gels and fluoride dentifrices. Marginal sealing deficiency and the absence of fluoride release by the materials have been reported as possibly responsible for the development of caries lesions. (18). When failure occurs in the adhesion of orthodontic brackets to enamel, rebonding is required, thus extending the duration of the orthodontic treatment (19). Reynolds and Fraunhofer in 1976 (20), reported that an average strength of the brackets adhesion from 5.6 MPa to 6.8 $\mathrm{MPa}$, would be enough for a good clinical performance, resisting to orthodontic and masticatory forces. In the present study, the values obtained were greater than 12.7 $\mathrm{MPa}$, independent of the used radiation and cement.

According to the results of this study, there was no difference in shear force between brackets bonded with composite (Transbond XT) and resin-modified glass ionomer cement (Fuji Ortho LC), regardless of the subgroup (radiated and non-radiated). This result may be related to the conditioning of dental enamel, of the adhesive system and, in the case of Fuji Ortho LC, the presence of polymerizable organic monomers in the composition, which increases the strength of this material.

However, the group where the conventional glass ionomer cement was used showed lower adhesion values compared to the other groups $(p<0.05)$. The glass ionomer cement has the ability to join chemically to the tooth structure, due to the connection between the carboxyl groups from polyacids, of the material and calcium ions in the dental structure (12). Although chemical coupling procedure to tooth structure is a very positive characteristic of this material, it is known that its adhesive strength is considered low when compared to composite materials $(13,21)$.

Although it is essential that the fixing material have strong adhesion to the enamel, this same glue must be brittle enough to avoid cohesive failures on the enamel surface during the bracket removal. Thus, by removing the bracket after completion of the orthodontic treatment, it is desired that a greater amount of residual adhesive remains on the tooth surface, decreasing the enamel fracture rates $(22,23)$.

In the present study, the brackets bonded with composites to irradiated teeth showed more cement remaining on the surface than in the non-radiated group, which is in agreement with the results found by Santin et al. (11). Moreover, the bond strength values were numerically higher after radiotherapy. An explanation for these findings would be the increased interprismatic region of enamel after ionizing radiation (9) and may result in increased permeability of the composite on the substrate, forming long tags, which would increase the composite adhesion to enamel, exceeding the cohesive adherence (11).

Among the groups bonded with conventional and resinmodified glass ionomer cements there was a predominance of adhesive failures, regardless of the subgroup (radiated or non-radiated). However, it is known that the adhesion of these materials to tooth enamel is not strong enough to cause damage to its surface in the event of removal $(24,25)$.

According to the in vitro results obtained in this study, it was observed that only the resin-modified glass ionomer cement showed similar resistance to orthodontic composite. Thus, it may be inferred that the resin-modified glass ionomer cement and the composite would be more suitable for bonding metal brackets in patients with radiotherapy history in the head and neck. The use of resin-modified glass ionomer cement could lead also to some fluoride ions release around the bracket, aiding the enamel remineralization.

Thus, the hypothesis that bracket bonding with glass ionomer cement may provide adequate retention to enamel after exposure to ionizing radiation, is accepted. However, additional studies are required to confirm, from the clinical point of view, if the bonding with resin resin-modified glass ionomer cement has a similar performance as bonding with composite resin.

\section{Resumo}

Pacientes submetidos a tratamento radioterápico apresentam maior suscetibilidade à cárie dentária e o uso de aparelho aumenta esse fator de risco devido ao acúmulo de biofilme dental ao redor dos bráquetes. Assim, o objetivo deste estudo foi avaliar a resistência ao cisalhamento de bráquetes ortodônticos colados com cimento de ionômero de vidro convencional (CIV) e o modificado por resina (CIVMR), devido à capacidade de liberação de flúor desse material em dentes permanentes irradiados. Noventa pré-molares humanos foram divididos em 6 grupos $(n=15)$, de acordo com o materila de colagem e com o uso ou não de radiação: RC: Transbond XT; CIVMR: Fuji Ortho LC; RMGIC: Ketac Cem Easymix. Os grupos for irradiados (I) ou não-irradiados (NI) previamente à colagem dos bráquetes. Os espécimes foram submetidos a doses fracionadas de radiação de $2 \mathrm{~Gy} /$ dia, durante 5 dias consecutivos, por 6 semanas. Depois da termociclagem e radioterapia, os bráquetes foram colados sobre os espécimes com Transbond XT, Fuji Ortho LC e Ketac Cem Easymix. Depois de 24 h, os espécimes foram sumetidos ao teste de resistência ao cisalhamento. A imagem da superfície do esmalte (classificado pelo Índice 
de Remanescente Adesivo-IRA) também foi avaliada. 0 IRA foi distribuido em tabelas de contingência e analisado quanto à frequência entre grupos/ subgrupos. 0 teste de resistência ao cisalhamento foi avaliado por ANOVA e pós-teste de Tukey. CIVMR apresentou os menores valores de adesão entre os grupos $(p<0,05)$. Entre os grupos irradiados e não-irradiados não houve diferença estatística significante $(p>0,05)$. Quanto ao IRA, RC-I apresentou maior retenção de compósito na superfície do esmalte do que os demais subgrupos. CIVMR pode ser utilizado para colagem de bráquetes metálico e apresentou IRA aceitável para práticas clínicas.

\section{References}

1. Franceschi D, Gupta R, Spiro RH, Shah JP. Improved survival in the treatment of squamous carcinoma of the oral tongue. Am J Surg 1993;166:360-365

2. Tromp DM, Brouha XD, Hordijk GJ, Winnubst JA, De Leeuw JR. Patient factors associated with delay in primary care among patients with head and neck carcinoma: a case series analysis. Farm Pract 2005;22:554559.

3. Kumar N, Broke A, Burke M, John R, O'Donnell A, Soldani F. The oral management of oncology patients requiring radiotherapy, chemotherapy and/or bone marrow transplantation. Faculty Dental J 2013;4:200-203.

4. Mitus-Kenig M, Loboda M, Marcinkowska-Mitus A, Durka-Zajac M, Pawlowska E. Ortodontic treatment in oncological patients. Przegl Lek 2015;72:243-245.

5. Neill CC, Migliorati C, Trojan T, Kaste $S$, Karydis A, Rowland C, et al.. Experience and expertise regarding orthodontic management of childhood and adolescent cancer survivors. Am J Orthod Dentofacial Orthop 2015;148:765-770.

6. Shiboski CH, Hodgson TA, Ship JA, Schiodt M. Management of salivary hypofunction during and after radiotherapy. Oral Surg Oral Med Oral Pathol Oral Radiol Endod 2007;103 Suppl:S66.e1-e19

7. Vissink A, Mitchell JB, Baum MJ, Limesand KH, Jensen SB, Fox PC, et al.. Clinical Management of salivary gland hypofunction and xerostomia in head-and-neck cancer patients: successes and barriers. Int J Radiat Oncol Biol Phys 2010;78:983-991.

8. Rankin KV, Jones DL, Redding SW. Oral health in cancer therapy. A guide for health care professionals. 3rd ed. 2008. http://www.doep. org/images/OHCT_III_FINAL.pdf. Accessed: 14 December 2015.

9. Gonçalves LMN, Palma-Dibb RG, Paula-Silva FWG, Oliveira HF, NelsonFilho $P$, Silva $L A B$, et al.. Radiation therapy alters microhardness and microstructure of enamel and dentin of permanent human teeth. J Dent 2014; 42:986-992.

10. Mellara TS, Palma-Dibb RG, Oliveira HF, Paula-Silva FWG, Nelson-Filho $P$, Silva $R A B$, et al.. The effect of radiation therapy on the mechanical and morphological properties of the enamel and dentin of deciduous teeth-an in vitro study. Radiat Oncol 2014:9:30.

11. Santin GC, Palma-Dibb RG, Romano FL, Oliveira HF, Nelson Filho $P$, Queiroz AM. Physical and adhesive properties of dental enamel after radiotherapy and bonding of metal and ceramic brackets. Am J Orthod Dentofacial Orthop 2015;148:283-292.

12. Nicholson JW. Chemistry of glass-ionomer cements: a review. Biomaterials 1998;19:485-494.

13. Pithon MM, Santos RL, Oliveira MV, Ruellas ACO, Romano FL. Metallic brackets bonded with resin-reinforced glass ionomer cements under different enamel conditions. Angle Orthodontist 2006;76:700-704.

14. Amaechi BT, Higham SM, Edgar WM. Techniques for the production of dental eroded lesions in vitro. J Oral Rehabil 1999; 26:97-102.

15. Martins CV, Leoni GB, Oliveira HF, Arid J, Queiroz AM, Silva LA, et al.. Influence of therapeutic cancer radiation on the bond strength of an epoxy - or an MTA-based sealer to root dentine. Int Endod J 2016;49:1065-1072.

16. Artun J, Bergland S. Clinical trials with crystal growth conditioning as an alternative to acid-etch enamel pretreatment. Am J Orthod 1984;85:333-340.

17. Billington RW, Williams JA, Dorban A, Pearson GJ. Glass ionomer cement: evidence pointing to fluoride release in the form of monofluorophosphate in addition to fluoride ion. Biomaterials. 2004; 25:3399-3402.

18. Wiegand A, Buchalla W, Attin T. Review on fluoride-releasing restorative materials - Fluoride release and uptake characteristics, antibacterial activity and influence on caries formation. Dent Mater. 2007;23:343-362.

19. Santos JE, Quioca J, Loguercio AD, Reis A. Six-month bracket survival with a self-etch adhesive. Angle Orthodontist 2006;76:863-868.

20. Reynolds IR, Fraunhofer JA. Direct bonding in orthodontics: A comparison of attachments. Br J Orthod 1976;4:65-69.

21. Mount JG. Clinical performance of glass-ionomers. Biomaterials 1998;19:573-579.

22. Romano FL, Tavares SW, Nouer DF, Consani S, Borges de Araújo Magnani MB. Shear bond strength of metallic orthodontic brackets bonded to enamel prepared with self-etching primer. Angle Orthod 2005;75:849853.

23. Pont $H B$, Özcan $M$, Bagis $B$, Ren $Y$. Loss of surface enamel after bracket debonding: An in-vivo and ex-vivo evaluation. Am J Orthod Dentofacial Orthop 2010;138:387.e1-387.e9.

24. Mccarthy MF, Hondrum SO. Mechanical and bond strength properties of light-cured and chemically cured glass ionomer cements. Am J Orthod Dentofacial Orthop 1994;105:135-141.

25. David VA, Staley RN, Bigelow HF, Jakobsen JR. Remnant amount and cleanup for 3 adhesives after debracketing. Am J Orthod Dentofacial Orthop 2002;121: 291-296. 